\title{
Pergeseran Aturan Netralitas Aparatur Sipil Negara dalam Pemilihan Umum
}

\author{
Bagus Sarnawa
}

DATA NASKAH:

Masuk: 27 Desember 2017

Diterima: 10 September 2018

Terbit: 31 Desember 2018

KORESPONDEN PENULIS:

Fakultas Hukum, Universitas

Muhammadiyah Yogyakarta

Jalan Brawijaya, Tamantirto, Kasihan,

Yogyakarta, 55183, Indonesia

email: bagussarnawa@umy.ac.id

\section{ABSTRACT}

The State Civil Apparatus (ASN) is the executor of government and development tasks. Therefore the ASN must be neutral. Based on Law Number 5 of 2014, the neutrality of the ASN is free from the influence and intervention of all political parties and groups. To maintain and guarantee the neutrality the integrity, cohesiveness, and unity of the State Civil Apparatus from the influence of political parties and to focus all attention, mind and energy on the tasks charged, the ASN is prohibited from becoming a member and/or administrator of political parties. In the past, the neutrality of the ASN began in the Old Order, when the issuance of Presidential Regulation Number 2 of 1959 concerning the Prohibition of Civil Servants and Public Officials in Political Parties. Furthermore, this Presidential Regulation was followed up and expanded with a Circular Letter of the President of the Republic of Indonesia Number 2 of 1959 concerning Prohibition of Membership of Political Parties for State Officials that Carry Out State Obligations Outside of Positions which they hold. Furthermore, in the New Order period, Law Number 8 of 1974 concerning the Principles of Staffing, while during the Reform Order was issued, among others, Law Number 43 of 1999, Civil servants must be neutral from the influence of all groups and parties and not discriminatory in providing services to the public. And the Reform Order was issued Law Number 5 of 2014 and other regulations related to the neutrality of the ASN

Keywords: Neutrality, State Civil Apparatus, Political Parties

\section{ABSTRAK}

Aparatur Sipil Negara (ASN) merupakan pelaksana tugas pemerintahan dan pembangunan. Oleh sebab itu ASN harus netral. Berdasarkan Undang Undang Nomor 5 Tahun 2014, netralitas ASN adalah bebas dari pengaruh dan intervensi semua golongan dan partai politik. Dalam upaya menjaga netralitas ASN dari pengaruh partai politik dan untuk menjamin keutuhan, kekompakan, dan persatuan ASN, serta dapat memusatkan segala perhatian, pikiran, dan tenaga pada tugas yang dibebankan, maka ASN dilarang menjadi anggota dan/atau pengurus partai politik. Pengaturan netralitas ASN sebenarnya sudah dimulai sejak masa Orde Lama. Pada masa tersebut netralitas ASN sudah diatur dengan 
diterbitkannya Peraturan Presiden Nomor 2 Tahun 1959 tentang Larangan Pegawai Negeri Sipil dan Pejabat Negeri dalam Partai Politik. Selanjutnya Peraturan Presiden ini ditindaklanjuti dan diperluas dengan Surat Edaran Presiden Republik Indonesia Nomor 2 Tahun 1959 tentang Larangan Keanggotaan Partai Politik bagi Pejabat Negeri yang Menjalankan Kewajiban Negara diluar Jabatan yang dipangkunya. Selanjutnya pada masa Orde Baru, Undang Undang Nomor 8 Tahun 1974 tentang Pokok Pokok Kepegawaian, Sedangkan pada masa Orde Reformasi diterbitkan antara lain Undang Undang Nomor 43 Tahun 1999, Pegawai negeri harus netral dari pengaruh semua golongan dan partai serta tidak diskriminatif dalam memberikan pelayanan kepada masyarakat. Dan pada Orde Reformasi diterbitkan Undang Undang Nomor 5 Tahun 2014 dan peraturan lain yang terkait dengan netralitas ASN

Kata Kunci : Netralitas, Aparatus Sipil Negara, Partai Politik

\section{PENDAHULUAN}

Sebagai pelaksana tugas umum pemerintahan dan pembangunan, maka Aparatur Sipil Negara (ASN) wajib berlaku netral. Menurut Mifthah Thoha (2008: 8) netralitas ASN diartikan sebagai tidak terpengaruhnya Pegawai Negeri Sipil (PNS) terhadap intervensi partai politik sehingga PNS dapat memusatkan segala perhatian, pikiran, dan tenaga pada tugas yang dibebankan, hal ini dilakukan dengan melarang PNS menjadi anggota dan atau pengurus partai politik.

Sementara menurut Amin (2013: 16-17), netralitas ASN adalah perilaku yang tidak memihak, atau tidak terlibat yang ditunjukan birokrasi pemerintahan dalam masa kampanye kandidat kepala daerah di ajang pemilukada baik secara diam-diam maupun terang-terangan. Adapun indikator yang digunakan untuk mengukur netralitas adalah (a) Tidak terlibat, dalam arti tidak menjadi tim sukses calon kandidat pada masa kampanye atau menjadi peserta kampanye baik dengan menggunakan atribut partai atau atribut PNS. (b) Tidak memihak, dalam arti tidak membantu dalam membuat keputusan dan/atau tindakan yang menguntungkan salah satu pasangan calon, tidak mengadakan kegiatan yang mengarah kepada keberpihakan terhadap salah satu pasangan calon Kepala Daerah/Wakil Kepala Daerah pada masa kampanye meliputi pertemuan, ajakan, himbauan, seruan, atau pemberian barang kepada PNS dalam lingkup unit kerjanya, anggota keluarga, dan masyarakat, serta tidak membantu dalam menggunakan fasilitas negara yang terkait dengan jabatan dalam rangka pemenangan salah satu calon pasangan Kepala Daerah/Wakil Kepala Daerah pada masa kampanye.

Secara normatif, menurut Undang Undang Nomor 5 tahun 2014 tentang Aparatur Sipil Negara, netralitas diartikan bebas dari pengaruh dan intervensi semua golongan dan partai politik. Dalam upaya menjaga netralitas Aparatur Sipil Negara dari pengaruh partai politik dan untuk menjamin keutuhan, kekompakan, dan persatuan Aparatur Sipil Negara, serta dapat memusatkan segala perhatian, pikiran, dan tenaga pada tugas yang dibebankan, maka ASN dilarang menjadi anggota dan/atau pengurus partai politik.

Dengan demikian makna netralitas adalah bebasnya PNS dari pengaruh kepentingan partai politik tertentu dan tidak memihak untuk kepentingan partai tertentu atau tidak berperan dalam proses politik karena dikhawatirkan pegawai tersebut menyalahgunakan penggunaan fasilitas negara untuk kepentingan partai politik (Hartini, et.all, 2014: 80)

Netralitas ASN dalam artikel ini merupakan netral dalam pelaksanaan pemilihan umum, yang meliputi: 1) netral dalam pelaksanaan pemilihan presiden, 2) netral dalam pemilihan anggota legislatif dan 3) netral dalam pemilihan umum kepala daerah. Netralitas ASN dalam pemilihan kepala daerah ini lah yang sering menimbulkan permasalahan. Permasalahan tersebut adalam munculnya praktek 
politisasi birokrasi oleh para kepala daerah yang merupakan pejabat politik.

Today, issue of bureaucracy neutrality this case the civil servants has become an important thing in context the regional area especially in term of regional elections. In that process to vote for the regional government head, bureaucratic position, then asked to be neutral institutionalized. The bureaucracy potentiality to influence voters on a particular candidate as well as desire of candidates to win the election, then meet in the paradoxal where forces important of neutrality. Politicians have the potentiality to utilize the bureaucracy network for their interests in the political arena when that is possible for bureaucrats involve in that arena at least to achieve a higher position or simply to keep this position in the regional government structures. That is becoming inclination which emphasizes important issues of neutrality and the various implications related to the bureaucracy position (Tamma, 2016: 96)

Penelitian LIPI juga menunjukkan hal yang sama, bahwa terhadap beberapa Pemilukada di tahun 2005 menemukan ada sejumlah faktor yang menyebabkan birokrasi daerah ikut berpolitik, yakni kuatnya ketokohan (personality) yang menanamkan pengaruh kepada pegawai daerah, keinginan pegawai itu sendiri untuk segera mendapatkan jenjang karir yang lebih cepat, lemahnya sosialisasi institusi, maupun multitafsir atau monopoli tafsir terhadap aturan yang ada, hubungan patron-client, serta adanya peran shadow bureaucracy (LIPI, 2006: 6).

Demikian pula kasus intervensi kepala daerah incumbent yang mencalonkan dirinya kembali dalam pemilukada terhadap ASN, seperti yang terjadi di Kabupaten Bantul, Kota Yogyakarta, dan lain-lain. Tabel 1 di bawah ini menunjukkan terjadi peningkatan jumlah pelanggaran netralitas ASN sejak tahun 2015 sampai dengan 2017.
Tabel 1.

Pelanggaran Netralitas ASN dalam Pemilukada dari tahun 2015 sampai dengan 2017

\begin{tabular}{|c|c|c|c|c|c|c|c|c|c|}
\hline \multirow{2}{*}{ Kategori } & \multirow{2}{*}{ Pemda } & \multicolumn{2}{|c|}{2015} & \multicolumn{2}{c|}{2016} & \multicolumn{2}{c|}{2017} & \multicolumn{2}{c|}{2018} \\
\cline { 2 - 11 } & $\begin{array}{c}\text { Sele } \\
\text { sai }\end{array}$ & $\begin{array}{c}\text { Pro } \\
\text { ses }\end{array}$ & $\begin{array}{c}\text { Sele } \\
\text { sai }\end{array}$ & $\begin{array}{c}\text { Pro } \\
\text { ses }\end{array}$ & $\begin{array}{c}\text { Sele } \\
\text { sai }\end{array}$ & $\begin{array}{c}\text { Pro } \\
\text { ses }\end{array}$ & $\begin{array}{c}\text { Sele } \\
\text { sai }\end{array}$ & $\begin{array}{c}\text { Pro } \\
\text { ses }\end{array}$ \\
\hline $\begin{array}{c}\text { Pelang- } \\
\text { garan } \\
\begin{array}{c}\text { Netrali- } \\
\text { tas }\end{array}\end{array}$ & $\begin{array}{c}\text { Kab/ } \\
\text { Kota }\end{array}$ & 28 & 0 & 43 & 0 & 25 & 9 & 12 & 29 \\
\cline { 2 - 11 } & 1 & 0 & 5 & 0 & 3 & 1 & 1 & 6 \\
\hline \multicolumn{2}{|c|}{ JUMLAH } & \multicolumn{2}{|c|}{29} & \multicolumn{2}{|c|}{48} & \multicolumn{2}{|c|}{38} & \multicolumn{2}{|c}{48} \\
\hline
\end{tabular}

Sumber : Komisi Aparatur Sipil Negara, 2017

\section{RUMUSAN MASALAH}

Berdasarkan uraian di atas maka dapat dirumuskan permasalahan sebagai berikut: "Bagaimanakah pergeseran aturan netralitas ASN di Indonesia dalam pemilihan umum?"

\section{PEMBAHASAN DAN ANALISIS}

Aturan netralitas Aparatur Sipil Negara sudah ada sejak diterbitkannya Peraturan Presiden Nomor 2 tahun 1959 tentang Larangan Pegawai Negeri Sipil dan Pejabat Negeri dalam Partai Politik. Peraturan Presiden ini diterbitkan untuk menyatukan Pegawai Negeri Sipil yang terkotak-kotak akibat kebijakan politik Nasakom. Selanjutnya Peraturan Presiden ini ditindaklanjuti dan diperluas dengan Surat Edaran Presiden Republik Indonesia Nomor 2 tahun 1959 tentang Larangan Keanggotaan Partai Politik bagi Pejabat Negeri yang Menjalankan Kewajiban Negara diluar Jabatan yang dipangkunya (Hartini, 2009: 261 262).

Sampai dengan tahun 1960, pemerintah banyak menerbitkan peraturan perundang-undangan kepegawaian dalam bentuk peraturan pemerintah. Akibat banyaknya peraturan tentang kepegawaian tersebut mengakibatkan sulit bagi aparat pemerintah untuk mendapatkan landasan hukum terhadap permasalahan-permasalahan kepegawaian yang tepat. Hal ini melatarbelakangi pemerintah untuk menyusun undang undang kepegawaian. Pada tahun 1958, pemerintah membentuk panitia yang diketuai 
oleh Prajudi Atmosudirdjo untuk menyusun undang undang kepegawaian. Akhirnya pada tahun 1961, melalui proses hukum berhasil diundangkan Undang Undang Nomor 18 tahun 1961 tentang ketentuan pokok Kepegawaian (Satoto, 2004: 31).

Undang Undang Nomor 18 tahun 1961 dibentuk untuk menjamin kedudukan hukum pegawai negeri, serta untuk dijadikan dasar untuk menyusun aparatur Negara yang berdaya guna sebagai alat revolusi nasional berdasarkan proklamasi kemerdekaan. Undang undang ini walaupun bernama Ketentuan Pokok Kepegawaian, berlaku tidak saja pada pegawai negeri namun berlaku juga bagi anggota-anggota Angkatan Perang, Kepolisian Negara serta Pegawai-pegawai perusahaan Negara.

Dalam pasal 10 ayat (4) undang undang tersebut, disebutkan bahwa "bagi suatu golongan pegawai dan/atau suatu jabatan, yang karena sifat atau tugasnya memerlukan dapat diadakan larangan masuk suatu organisasi politik, ketentuan mengenai hal ini ditetapkan dengan peraturan pemerintah". Dalam prakteknya, Pegawai Negeri Sipil terkotakkotak dalam partai politik sebagai akibat situasi politik dan pemerintahan. Pada saat itu partai-partai politik mulai menanamkan pengaruhnya terhadap aparat pemerintah dan menggunakan pejabat pemerintah sebagai building block organisasi mereka. Partai-partai politik mempunyai masa pengaruh dan masa pendukung di setiap departemen, atau bahkan mendominasi departemen. Dengan demikian intervensi politik dalam kehidupan birokrasi sangat besar sekali. Maklumat Wakil Presiden tanggal 3 Nopember 1945 telah menimbulkan sistem multi partai yang memberikan kebebasan kepada masyarakat untuk mendirikan partai politik sesuai dengan aspirasinya. Pada masa itu dilaksanakan Pemilihan Umum yang pertama. Dari hasil pemilihan umum tersebut, partai-partai politik yang memenangkan suara berkehendak untuk menguasai beberapa kementrian. Bahkan tidak jarang terjadi kabinet pemerintahan dibubarkan hanya karena pembagian kementrian yang tidak sesuai dengan tuntutan partai-partai politik. Pemerintah dibawah kepemimpinan partai politik yang anggotanya mendominasi Dewan Perwakilan Rakyat. Kedudukan Dewan Perwakilan Rakyat sangat kuat. Sebaliknya lembaga-lembaga pemerintah kedudukannya sangat lemah. Pegawai Negeri Sipil yang seharusnya loyal kepada negara dan bangsa Indonesia akan tetapi dalam kenyataannya menjadi loyalis partai-partai politik (Thoha, 2010: 115-132).

Pada masa itu, PNS terkontaminasi terhadap bermacam perbedaan ideologi yang dibawa oleh partai-partai politik, banyak kasus yang terjadi dimana partai politik yang memimpin suatu kementrian maka akan tertanam pengaruh partai dalam kementrian tersebut, seluruh PNS dalam kementrian itu dipastikan adalah pendukung partai politik itu, akibatnya PNS menjadi terkotak-kotak. Dengan demikian aturan netralitas PNS pada larangan untuk menjadi anggota atau pengurus partai politik.

Pada awal pemerintahan Orde Baru, yang menggantikan pemerintahan Orde Lama, diterbitkan Permendagri Nomor 12 tahun 1968 yang antara lain berisi kewajiban aparat pemerintah untuk loyal kepada bangsa dan negara dan dilarang menjadi anggota partai politik. Aturan ini masih sama substansinya dengan aturan pada masa pemerintahan Orde Lama. Barulah pada tahun 1970, diterbitkan Peraturan Pemerintah Nomor 6 tahun 1970 yang mengharuskan setiap Pegawai Negeri untuk masuk dalam Korp Karyawan Departemen Dalam Negeri (Kokarmendagri), selanjutnya pada tahun 1971 berdasarkan Keputusan Presiden Nomor 82 tahun 1971 tentang Korps Pegawai Republik Indonesia (KORPRI), dibentuklah KORPRI sebagai satusatunya wadah pembinaan bagi Pegawai Negeri Sipil di luar kedinasan. Dikemudian hari KORPRI dijadikan kendaraan politik dan secara transparan berafiliasi kepada kekuatan politik tertentu.

Lebih lanjut pemerintah menerbitkan Undang Undang Nomor 8 tahun 1974 tentang Pokok Pokok Kepegawaian, dimana dalam Pasal 14 disebutkan "untuk lebih meningkatkan pembinaan, keutuhan 
dan kekompakan, serta dalam rangka usaha menjamin kesetiaan dan ketaatan penuh seluruh Pegawai Negeri Sipil terhadap Pancasila, Undang Undang Dasar 1945, Negara dan Pemerintah, maka perlu dipupuk dan dikembangkan jiwa korps yang bulat dikalangan Pegawai Negeri Sipil”. Aturan ini dimaksudkan untuk menyatukan Pegawai Negeri Sipil dalam satu korps yaitu KORPRI.

Pada tahun 1998 ketika terjadi pergantian kekuasaan dari Orde Baru kepada Orde Reformasi. Pada masa ini pengaturan netralitas PNS diatur pada Undang Undang Kepegawaian dan Undang Undang Pemilihan Umum. Pada tahun 1999, diterbitkanlah Undang Undang Nomor 43 tahun 1999. Undang undang ini sangat penting untuk diterbitkan karena terjadinya pergeseran fungsi pembangunan dan pemerintahan dari pusat ke daerah (Effendi, 1999: 4). Selama hampir 32 tahun pemerintahan Orde Baru, pemerintahan berlangsung sangat otoritarian dan sentralistik. Titik kekuasaan terpusat pada penguasa birokrasi pemerintah (Thoha, 2008: 1). Kendali pembangunan dan pemerintahan berada di tangan pemerintah pusat (Syaukani et.all, 2002: 168-169).

Berkaitan dengan hal ini reformasi membawa perubahan yang ditandai dengan penegasan terhadap desentralisasi tugas dan kewenangan dari pemerintah kepada pemerintah daerah berupa pemberian otonomi kepada daerah. Pemberian otonomi luas kepada daerah diarahkan untuk mempercepat terwujudnya kesejahteraan masyarakat melalui peningkatan pelayanan, pemberdayaan dan peran serta masyarakat. Di samping itu melalui otonomi luas, daerah diharapkan mampu meningkatkan daya saing dengan memperhatikan prinsip demokrasi, pemerataan, keadilan, keistimewaan dan kekhususan serta potensi dan keanekaragaman daerah dalam sistem Negara Kesatuan Republik Indonesia.

Pada saat itu, situasi seperti pada masa Orde Lama terulang kembali. Partai-partai politik bermuculan. Partai-partai politik yang berkoalisi dan memenangkan Pemilihan Umum Presiden dan Wakil Presiden, mendapatkan hadiah untuk menguasai
Departemen-departemen, akibatnya netralitas Pegawai Negeri Sipil sangat terpengaruh.

Oleh sebab itu Undang Undang Nomor 43 tahun 1999 pasal 3 ayat (2), mengatur tentang netralitas Pegawai Negeri Sipil, yaitu :

"Dalam kedudukan dan tugas sebagaimana dimaksud dalam ayat (1), Pegawai negeri harus netral dari pengaruh semua golongan dan partai serta tidak diskriminatif dalam memberikan pelayanan kepada masyarakat".

Pada masa itu, diterbitkan juga Undang Undang 10 Tahun 2008 tentang Pemilihan Anggota DPR, DPD dan DPRD, yang mengatur tentng netralitas PNS. Dalam pasal 84 ayat (2) disebutkan bahwa pelaksana kampanye dalam kegiatan kampanye dilarang mengikutsertakan Pegawai Negeri Sipil, kemudian dalam Undang Undang Nomor 42 Tahun 2008 tentang Pemilihan Presiden dan Wakil Presiden juga menyebutkan hal yang sama, khususnya dalam Pasal 41 ayat (2), (4) dan ayat (5) yang menyebutkan bahwa Pegawai Negeri Sipil dilarang untuk dilibatkan dan diikutsertakan dalam kegiatan kampanye. Juga dalam Undang Undang Nomor 8 tahun 2012 tentang Pemilihan Umum, dalam pasal 86 ayat (2) diatur larangan pelibatan PNS dalam kegiatan kampanye.

Peraturan Pemerintah Nomor 14 tahun 2009 tentang Tata Cara bagi Pejabat Negara dalam Melaksanakan Kampanye Pemilihan Umum menyebutkan "Dalam melaksanakan Kampanye Pemilu, Pejabat Negara dilarang: a) menggunakan fasilitas negara; b) memobilisasi aparat bawahannya untuk kepentingan kampanye; c) menggunakan dan/atau memanfaatkan dana yang bersumber dari keuangan negara baik secara langsung maupun tidak langsung; dan/atau d) menggunakan fasilitas Badan Usaha Milik Negara dan Badan Usaha Milik Daerah".

Sebagai pelaksanaan Undang Undang Nomor 43 Tahun 1999, diterbitkanlah Peraturan Pemerintah Nomor 5 tahun 1999 tentang Pegawai Negeri Sipil yang menjadi Anggota Partai Politik. Adapun 
pengaturan tentang netralitas Pegawai Negeri Sipil tersurat dalam pasal 3 sampai dengan 9, ketentuan tersebut mengatur antara lain (1) Pegawai Negeri Sipil harus bersikap netral dan menghindari penggunaan fasilitas negara untuk golongan tertentu, (2) Pegawai Negeri Sipil yang telah menjadi anggota dan atau pengurus partai politik pada saat Peraturan Pemerintah ini ditetapkan dianggap telah melepaskan keanggotaan dan atau kepengurusannya. (3) Pegawai Negeri Sipil yang menjadi anggota dan atau pengurus partai politik diberhentikan dari jabatan negeri dan diberikan uang tunggu sebesar gaji pokok terakhir.

Selanjutnya diterbitkan Peraturan Pemerintah Nomor 12 tahun 1999 yang merubah beberapa pasal dalam Peraturan Pemerintah Nomor 5 tahun 1999 khususnya Pasal 7, 8 dan 9. Adapun ketentuan pasalpasal tersebut antara lain mengatur tentang penghapusan secara otomatis keanggotaan Pegawai Negeri Sipil dari keanggotaan dan kepengurusan partai politik

Pemerintah juga menerbitkan Peraturan Pemerintah Nomor 53 Tahun 2010 tentang Disiplin Pegawai Negeri Sipil juga mengatur tentang netralitas Pegawai Negeri Sipil. Hal ini dapat dilihat dalam pasal 4 yang menyebutkan bahwa Pegawai Negeri Sipil dilarang untuk memberikan dukungan kepada calon Presiden/Wakil Presiden, Dewan Perwakilan Rakyat, Dewan Perwakilan Daerah, atau Dewan Perwakilan Rakyat Daerah. Juga larangan untuk membuat keputusan dan/atau tindakan yang menguntungkan atau merugikan salah satu pasangan calon selama masa kampanye dan/atau mengadakan kegiatan yang mengarah kepada keberpihakan terhadap pasangan calon yang menjadi peserta pemilu sebelum, selama, dan sesudah masa kampanye meliputi pertemuan, ajakan, himbauan, seruan, atau pemberian barang kepada PNS dalam lingkungan unit kerjanya, anggota keluarga, dan masyarakat;

Selain itu Pegawai Negeri Sipil juga dilarang memberikan dukungan kepada calon anggota Dewan Perwakilan Daerah atau calon Kepala
Daerah/Wakil Kepala Daerah dengan cara memberikan surat dukungan disertai foto kopi Kartu Tanda Penduduk atau Surat Keterangan Tanda Penduduk sesuai peraturan perundang-undangan; dan memberikan dukungan kepada calon Kepala Daerah/Wakil Kepala Daerah, dengan cara: a. terlibat dalam kegiatan kampanye untuk mendukung calon Kepala Daerah/Wakil Kepala Daerah; b. menggunakan fasilitas yang terkait dengan jabatan dalam kegiatan kampanye; c. membuat keputusan dan/atau tindakan yang menguntungkan atau merugikan salah satu pasangan calon selama masa kampanye; dan/atau $\mathrm{d}$. mengadakan kegiatan yang mengarah kepada keberpihakan terhadap pasangan calon yang menjadi peserta pemilu sebelum, selama, dan sesudah masa kampanye meliputi pertemuan, ajakan, himbauan, seruan, atau pemberian barang kepada Pegawai Negeri Sipil dalam lingkungan unit kerjanya, anggota keluarga, dan masyarakat.

Aturan selanjutnya Kepala Badan Kepegawaian Negara menerbitkan Surat Kepala Badan Kepegawaian Negara Nomor K.26-17/V.19-14/99 perihal Pegawai Negeri Sipil yang menjadi anggota partai politik, menyebutkan bahwa Pegawai Negeri harus netral dari pengaruh semua golongan dan partai politik serta tidak diskriminatif dalam memberikan pelayanan kepada masyarakat. Untuk menjamin netralitas Pegawai Negeri, maka Pegawai Negeri dilarang menjadi anggota dan atau pengurus partai politik. Dalam upaya menjaga netralitas Pegawai Negeri dari pengaruh partai politik dan untuk menjamin keutuhan, kekompakan, dan persatuan pegawai Negeri, serta agar dapat memusatkan segala perhatian, pikiran, dan tenaganya pada tugas yang dibebankan kepadanya, maka Pegawai Negeri dilarang menjadi anggota dan atau pengurus partai politik. Oleh karena itu, Pegawai Negeri yang menjadi anggota dan atau pengurus partai politik harus diberhentikan sebagai Pegawai Negeri. Pemberhentian tersebut dapat dilakukan dengan hormat atau tidak dengan hormat. 
Berkaitan dengan sanksi bagi Pegawai Negeri Sipil yang tidak netral maka Menteri Pendayagunaan Aparatur Negara menerbitkan Surat Edaran Menteri Pendayagunaan Aparatur Negara Nomor: SE/18.1/M.PAN/5/2004. Surat edaran ini mengatur tentang kriteria penjatuhan sanksi bagi Pegawai Negeri Sipil yang tidak netral. Kriteria tersebut adalah a). Hukuman disiplin tingkat berat berupa penurunan pangkat setingkat lebih rendah untuk paling lama 1 (satu) tahun bagi PNS yang terlibat dalam kampanye pemilihan umum Presiden dan Wakil Presiden atau mengizinkan penggunaan fasilitas pemerintah karena jabatannya. b). Hukuman disiplin tingkat berat berupa pembehentian dengan hormat tidak atas permintaan sendiri sebagai Pegawai Negeri Sipil dengan hak-hak kepegawaian sesuai peraturan perundang-undangan yang berlaku, bagi Pegawai Negeri Sipil yang terlibat dalam kampanye dan berkedudukan sebagai Tim sukses atau yang sejenis dalam pemilihan umum Presiden dan wakil Presiden. c). Hukuman disiplin tingkat berat berupa pemberhentian tidak dengan hormat sebagai Pegawai Negeri Sipil, bagi Pegawai Negeri Sipil yang terlibat dalam kampanye Pemilu Presiden dan Wakil Presiden berkedudukan sebagai anggota atau pengurus Partai Politik atau Tim sukses atau sejenis dalam Pemilu Presiden dan Wakil Presiden serta menggunakan fasilitas oleh karena jabatannya.

Pada tahun 2014, diterbitkan Undang Undang Nomor 5 tahun 2014 tentang Aparatur Sipil Negara untuk menggantikan Undang Undang Nomor 43 tahun 1999. Dalam pasal 12 disebutkan bahwa Pegawai Aparatur Sipil Negara berperan sebagai perencana, pelaksana, dan pengawas penyelenggaraan tugas umum pemerintahan dan pembangunan nasional melalui pelaksanaan kebijakan dan pelayanan publik yang profesional, bebas dari intervensi politik, serta bersih dari praktik korupsi, kolusi, dan nepotisme.

Undang Undang ini diterbitkan karena terjadi politisasi birokrasi oleh pejabat pembina kepegawaian. Sebagaimana disebutkan dalam
Peraturan Pemerintah Nomor 9 tahun 2003 tentang Wewenang Mengangkat, Memindahkan dan Memberhentikan Pegawai Negeri Sipil, maka Pejabat pembina kepegawaian mempunyai kewenangan yang sangat luas dalam hal manajemen Pegawai Negeri Sipil yaitu keseluruhan upaya-upaya untuk meningkatkan efisiensi, efektifitas dan derajat profesionalisme penyelenggaraan tugas, fungsi dan kewajiban kepegawaian yang meliputi perencanaan, pengadaan, pengembangan kualitas, penempatan, promosi, penggajian, kesejahteraan dan pemberhentian. Akibatnya pejabat Pembina Kepegawaian seperti Kepala daerah seringkali melakukan politisasi birokrasi dengan mempengaruhi Pegawai Negeri Sipil dilingkungannya untuk memberikan dukungan kepada partai politik yang menjadi afiliasi Kepala Daerah tersebut.

Undang Undang Nomor 7 tahun 2017 juga mengatur tentang netralitas Aparatur Sipil Negara, dalam Pasal 280 ayat (2) menyebutkan "Pelaksana dan/atau tim kampanye dalam kegiatan Kamparrye Pemilu dilarang mengikrrtsertakan Aparatur Sipil Negara”. Kemudian pasal 283 ayat (1) yang menyebutkan "aparatur sipil negara lainnya dilarang mengadakan kegiatan yang mengaratr kepada keberpihakan terhadap Peserta pemilu sebelum, selama, dan sesudah masa kampanye".

\section{SIMPULAN}

Berdasarkan uraian di atas, dapat disimpulkan bahwa aturan netralitas ASN mengalami pergeseran sesuai pada masanya. Pada masa Orde Lama, dimana ASN terkotak-kotak dalam keanggotaan partai politik maka aturan netralitas ASN pada waktu itu adalah larangan untuk menjadi anggota partai politik sesuai dengan ketentuan Peraturan Presiden Nomor 2 tahun 1959 dan Surat Edaran Presiden Republik Indonesia Nomor 2 tahun 1959. Pada masa Orde Baru, aturan netralitas ASN, diartikan sebagai kesatuan korps, sebagai upaya menyatukan kembali ASN yang terkotak-kotak dalam afiliasi partai politik, hal ini sesuai dengan Peraturan Pemerintah Nomor 6 
tahun 1970 dan Keputusan Presiden Nomor 82 tahun 1971, disamping itu juga terdapat aturan tentang larangan PNS menjadi anggota partai politik yaitu sesuai dengan Permendagri Nomor 12 tahun 1968. Pada masa Orde Reformasi, netralitas ASN tidak saja larangan untuk menjadi anggota partai politik namun juga dalam pelaksanaan pemilihan umum anggota legislatif sesuai dengan Undang Undang 10 Tahun 2008, serta dalam pelaksanaan pemilihan umum Presiden dan Wakil Presiden sesuai dengan Undang Undang Nomor 42 Tahun 2008. Selanjutnya dalam Undang Undang Nomor 5 tahun 2014 mengatur tentang netralitas ASN sebagai terbebsanya ASN dari intervensi politik. Demikian juga dalam Undang Undang Nomor 7 tahun 2017. ASN tidak diperbolehkan menjadi anggta atau pengurus partai politik, serta dilarang terlibat dalam kegiatan kampanye dalam pelaksanaan pemilihan umum baik pemilihan presiden/waki presiden, pemilihan anggota legislatif maupun pemilihan kepala daerah.

\section{DAFTAR PUSTAKA}

\section{Buku}

Amin, 2013, Netralitas Birokrat Pemerintahan pada Dinas Pendidikan Kota Makassar dalam Pemilukada di Kota Masakar (Pemilihan Walikota Makassar Tahun 2008), Makasar, Fakultas Ilmu Sosial dan Ilmu Politik Universitas Hasanuddin.

Azhary, 1995, Indonesia Negara Hukum: Analisis Yuridis Normatif tentang Unsur-Unsurnya, Jakarta, UI Press.

Beetham, David, 1996, Bureaucracy, Second Edition, Buckingham, Open University Press.

Hadjon, Philipus M dkk., 1999, Pengantar Hukum

Administrasi Indonesia, Yogyakarta, Gadjah Mada University Press.

Hadjon, Philipus M dkk., 2007, Perlindungan Hukum Bagi Rakyat Indonesia, Jakarta, Peradaban.
Hartini, Sri dkk., 2014, Hukum Kepegawaian di Indonesia, Jakarta, Sinar Grafika.

Karianga, Hendra, 2013, Politik Hukum dalam Pengelolaan Keuangan Daerah, Jakarta, Kencana Prenada Media.

Mahfud, 2001, Politik Hukum Indonesia, Jakarta, LP3ES.

Mahfud, 1999, Pergulatan Politik dan Hukum di Indoensia, Yogyakarta, Gama Media.

Patria, A, 2015, Intervensi Politik dan Netralitas Aparatur Sipil Negara dalam Pemilihan Umum Kepala Daerah Provinsi Lampung Tahun 2014, Bandar Lampung, Fakultas Ilmu Sosial dan Ilmu Politik Universitas Lampung.

Purba, L. A, 2010, Netralitas Pegawai Negeri Sipil dalam Pemilihan Kepala Daerah secara Langsung, Jakarta, Universitas Indonesia.

Raharjo, Satjipto, 2000, Ilmu Hukum, Bandung, Citra Aditya Bakti.

Satoto, Sukamto, 2004, Pengaturan Eksistensi dan Fungsi Badan Kepegawaian Negara, Yogyakarta, CV Hanggar Kreator

Setiono, Budi, 2002, Jaring Birokrasi, Sautu Tinjauan dari Aspek Politik dan Administrasi, Bekasi, Gugus Press.

Sukiyoprapti, Hayu dan Bagus Sarnawa, 2007, Menjemen Pegawai Negeri Sipil (suatu pengantar), Yogyakarta, Laboratorium Ilmu Hukum UMY.

Syaukani, Affan Gaffar dan Ryaas Rasyid, 2002, Otonomi Daerah dalam Negara Kesatuan, Yogyakarta, Pustaka Pelajar.

Tayibnapsis, Burhanuddin, 1995, Administrasi Kepegawaian suatu Tinjauan Analitik, Jakarta, PT Pradnya Paramita.

Thoha, Miftah, 1997, Adminsitrasi Kepegawaian Daerah, Jakarta, Ghalia.

Thoha, Miftah, 2008, Menejemen Kepegawaian Sipil di Indonesia, Jakarta, Kencana Predana Media Group.

Thoha, Miftah, 2010, Birokrasi dan Politik di Indonesia, Jakarta, Rajawali Press. 
Thoha, Miftah, 2010, Ilmu Administrasi Publik Kontemporer, Jakarta, Media Grafika.

Tjokrowinoto, Moeljarto, 2004, Birokrasi dalam Polemik, Yogyakarta, Pustaka Pelajar.

Wahyono, Padmo, 1986, Indonesia Negara Berdasar Hukum, Jakarta, Depdagri.

Warsito Utomo, 2006, Administrasi Publik Baru Indonesia: Perubahan Paradigma dari Administrasi Negara ke Administrasi Publik, Yogyakarta, Pustaka Pelajar.

Watunglawar, 2015, Perwujudan Asas Netralitas Birokrasi dalam Undang-Undangn Nomor 5 Tahun 2014 Tentang Aparatur Sipil Negara, Jember, Program Pacasarjana Universitas Jember.

Yamin, 2013, Netralitas Pegawai Negeri Sipil dalam Pemilihan Umum Kepala Daerah di Kabupaten Takalar, Makasar, Bagian Hukum Tata Negara Fakultas Hukum Universitas

\section{Jurnal}

Agius, C. and K. Devine, 2011, "Neutrality: A Really Dead Concept?' A Reprise," Cooperation and Conflict, Vol. 46 No. 3.

Hartini, Sri, 2009, "Penegakkan Hukum Netralitas PNS”, Jurnal Dinamika Hukum, Vol. 9 No. 3.

Tamma, Sukri, 2016, "Paradox Of Bureaucracy Neutrality In The Indonesia Regional Election”, PALITA: Journal of Social-Religion Research, Vol. 1 No. 2.

\section{Makalah}

Effendi, Sofian, 1999, “Kebijakan Kepegawaian Negara dalam Rangka Penyelenggaraan Pemerintahan pasca Pemilu 1999”, makalah, tidak diterbitkan.

\section{Peraturan Perundang-undangan}

Undang Undang Nomor 18 Tahun 1961 tentang Ketentuan Pokok Kepegawaian

Undang Undang Nomor 8 Tahun 1974 tentang Pokok Pokok Kepegawaian
Undang Undang Nomor 43 Tahun 1999 tentang Perubahan atas Undang Undang Nomor 8 tahun 1974 tentang Pokok Pokok Kepegawaian

Undang Undang Nomor 5 Tahun 2014 tentang Aparatur Sipil Negara

Peraturan Pemerintah Nomor 4 Tahun 1966 tentang Pemberhentian/Pemberhentian Sementara Pegawai Negeri

Peraturan Pememrintah Nomor 6 Tahun 1970 tentang Pengaturan Kehidupan Politik PejabatPejabat Negeri dalam rangka Pembinaan Sistim Kepegawaian Negeri Republik Indonesia

Peraturan Pemerintah Nomor 5 Tahun 1999 tentang Pegawai Negeri Sipil yang menjadi Anggota Partai Politik

Peraturan Pemerintah Nomor 12 Tahun 1999 tentang Perubahan atas Peraturan Pemerintah Nomor 5 tahun 1999 tentang Pegawai Negeri Sipil yang menjadi Anggota Partai Politik

Peraturan Pemerintah Nomor 42 Tahun 2004 tentang Pembinaan Jiwa Korps dan Kode Etik Pegawai Negeri Sipil

Peraturan Pemerintah Nomor 53 Tahun 2010 tentang Disiplin Pegawai Negeri Sipil

Keputusan Presiden Nomor 82 Tahun 1971 tentang Jorps Pegawai Republik Indonesia

Surat Kepala Badan Kerpegawaian Negara Nomor K.26-17/V.19-14/99 perihal Pegawai Negeri Sipil yang Menjadi Anggota Partai Politik

Surat Edaran Menteri Pendayagunaan Aparatur Negara Nomor: SE/18.1/M.PAN/5/2004 tentang Kriteria Penjatuhan Sanksi bagi Pegawai Negeri Sipil yang Tidak Netral 